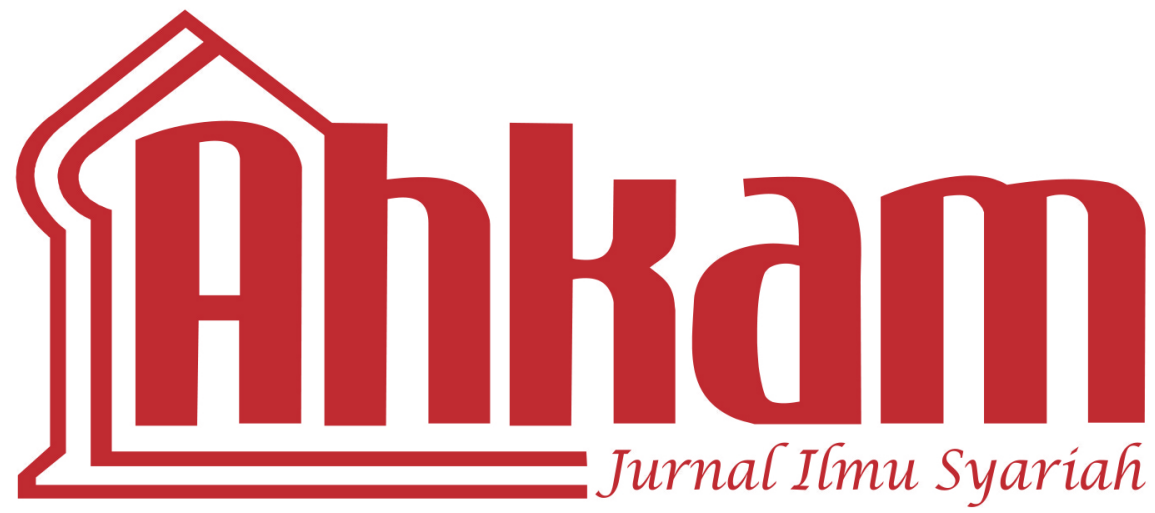

* Khamami Zada

The Rohingya's Muslim Asylum Seekers in Southeast Asia: From National to International Law Perspective

* Ilyya Muhsin

Endogamous Marriage of Jamaah Tarbiyah: A Sociological Study of The Jamaah Tarbiyah in Salatiga

* Muhammad Maksum

Building Flats Through Waqf Land: Legal Breakthrough and Obstacles

* Mustapa Khamal Rokan

Conceptualization of Economic Right for Small Traders at Traditional Market in Indonesia

* Fauzan \& Anis Fuadah Zuhri

Analysing the Essence of Fiqh Subjects in Curriculum 2013

* Amany Burhanuddin Lubis

Al-Shurūt wa al-Ḍawābiṭ al-Shar iyyah li al-Ghidä’ al-Haläl: Khibrah Indūnisiyā 


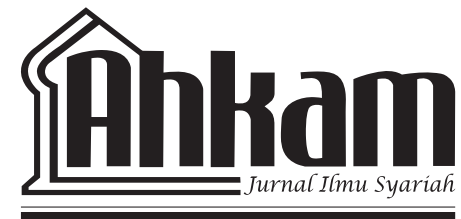

Volume 17, Number 1, 2017

\section{EDITOR-IN-CHIEF}

Ahmad Tholabi Kharlie

\section{EDITORS}

Arip Purkon

Fathuddin

Maman R Hakim

Ahmad Bahtiar

\section{INTERNATIONAL EDITORIAL BOARD}

Tim Lindsey (University of Melbourne Australia)

Nadirsyah Hosen (Monash University Australia)

Ahmad Hidayat Buang (Universiti Malaya Malaysia)

Raihanah Azahari (Universiti Malaya Malaysia)

Mark Elwen Cammack (Southwestern University)

Razeen Sappideen (University of Western Sydney)

Carolyn Sappideen (University of Western Sydney)

Nik Ahmad Kamal bin Nik Mahmod (International Islamic University Malaysia)

Muhammad Atho Mudzhar (UIN Syarif Hidayatullah Jakarta)

Masykuri Abdillah (UIN Syarif Hidayatullah Jakarta)

Muhammad Amin Suma (UIN Syarif Hidayatullah Jakarta)

M. Arskal Salim GP (UIN Syarif Hidayatullah Jakarta)

Asep Saepudin Jahar (UIN Syarif Hidayatullah Jakarta)

\section{ASSISTANT TO THE EDITORS}

M. Ishar Helmy

Erwin Hikmatiar

ENGLISH LANGUAGE ADVISOR

Bradley Holland

Umi Kulsum

ARABIC LANGUAGE ADVISOR

Amany Burhanuddin Lubis

AHKAM has been accredited based on the determination of Director General of Research Reinforcement and Development, Research, and Technology Ministry of Higher Education of Republic of Indonesia, No. 36/a/E/KPT/2016 (valid until 2021). 
AHKAM Jurnal Ilmu Syariah (ISSN: 1412-4734) is a periodical scientific journal published by Faculty of Sharia and Law of Syarif Hidayatullah State Islamic University Jakarta in collaboration with Indonesian Scientist and Sharia Scholar Association (HISSI). This journal specifically examines the science of sharia and obtains to present various results of current and eminence scientific research. The administrators receive articles as contributions Sharia and Islamic law disciplines from scientists, scholars, professionals, and researchers to be published and disseminated.

\section{EDITORIAL OFFICE:}

Fakultas Syariah dan Hukum UIN Syarif Hidayatullah Jakarta

Jl. Ir. H. Juanda 95 Ciputat, Jakarta 15412

Telp. (+62-21) 74711537, Faks. (+62-21) 7491821

Website: http://journal.uinjkt.ac.id/index.php/ahkam/index

E-mail: Jurnal.ahkam@uinjkt.ac.id 
Khamami Zada

The Rohingya's Muslim Asylum Seekers in Southeast Asia: From National to International Law Perspective

25 ILYYA MuHsin

Endogamous Marriage of Jamaah Tarbiyah: A Sociological Study of The Jamaah Tarbiyah in Salatiga

47 Muhammad Maksum

Building Flats Through Waqf Land: Legal Breakthrough and Obstacles

65 Mustapa Khamal Rokan

Conceptualization of Economic Right for Small Traders at Traditional Market in Indonesia

93 Fauzan \& Anis Fuadah Zuhri Analysing the Essence of Fiqh Subjects in Curriculum 2013 
113 Abdul Rouf

Kriteria Hukum Fikih Ja'farī

133 Fuad Thohari, Achmad Sasmito, Andy ES, Jaya Murjaya, Rony Kurniawan

Kondisi Metereologi Saat Pengamatan Hilal 1 Syawal $1438 \mathrm{H}$ di Indonesia: Upaya Peningkatan Kemampuan Pengamatan dan Analisis Data Hilal

153 Azhari Akmal Tarigan

Ta'zir dan Kewenangan Pemerintah dalam

Penerapannya

171 Mujar IbNu Syarif

Syarat Kesehatan Fisik Bagi Calon Presiden dalam

Perspektif Politik Islam dan Politik Indonesia

199 Husni Mubarrak

Penalaran Istiṣlāhi dalam Kajian Fikih Kontemporer:

Studi Kasus Fatwa Hukum Imunisasi di Aceh

223 Yuser RafiQi

Kritik Hermeneutik dan Kontekstualisasi Ayat-Ayat Hukum

أماني برهان الدين لوبيس

الشروط والضوابط الشرعية للغذاء الحلال : خبرة إندونيسيا 


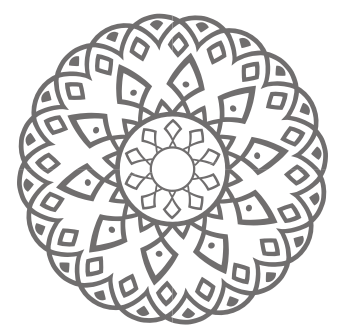

\title{
Analysing the Essence of Fiqh Subjects in Curriculum 2013
}

\author{
Fauzan \\ Anis Fuadah Zuhri
}

\begin{abstract}
Abstrak: Hakikat pembelajaran adalah upaya peningkatan kualitas peserta didik dalam mencapai tujuan pendidikan nasional sesuai amanat Undangundang Nomor 20 Tahun 2003 tentang Sistem Pendidikan Nasional. Upaya peningkatan mutu pendidikan direspon Kementerian Agama melalui kurikulum 2013 pada mata pelajaran Pendidikan Agama Islam (PAI) dan Bahasa Arab. Studi ini menganalisis esensi pembelajaran fikih pada kurikulum 13 di Madrasah Ibtidaiyah. Studi ini menyimpulkan bahwa penerapan kurikulum 2013 di Madrasah Ibtidaiyah pada mata pelajaran Fikih menjadi terobosan untuk melaksanakan proses pembelajaran yang lebih dinamis dan inovatif. Penggunaan metode yang variatif menambahkan keberhasilan dalam penerapan Fikih dalam kehidupan sehari-hari peserta didik, baik dalam ibadah maupun muamalah.
\end{abstract}

Kata kunci: fikih, kurikulum 2013, Madrasah Ibtidaiyah 
Abstract: The essence of learning is to improve the quality of learners and to complete the national education goals that have been established, in accordance with the mandate of the constitution. The effort to improve the quality of education through curriculum has been responded by the Ministry of Religious Affairs in 2013 on the subject of Islamic Education and Arabic Language. The implementation of the 2013 curriculum at public Elementary School, in this case is the subjects of Fiqh, become a breakthrough to conduct the learning process to be more dynamic and innovative. The uses of varied methods to teach fiqh are expected to make the application of Fiqh in the daily lives of learners; both in their worship to God ('ibädah) and social interaction (muamalah) become successful habit.

Keywords: fiqh, curriculum 2013, Elementary School

$$
\begin{aligned}
& \text { ملخص: التعليم في الحقيقة هو المحاولة في ترقية نوعية التلاميذ للوصول إلى أهداف التربية } \\
& \text { الوطنية الموفقة المناسبة لإنتداب الدستور الإندونيسية. وقد حاولت ولتهو وزارة الشؤون الدينية } \\
& \text { ترقية نوعية التربية من خلال تطبيق المنهج r • اس للمادتين التربية الإسلامية واللغة العربية. } \\
& \text { وقد أصبح تطبيق المنهج لمادة الفقه في المدرسة الإبتدائية إخترافا في سبيل ممارسة عملية } \\
& \text { التعليم لتكون أكثر ديناميكية وإبداعية. ويرجى استخدام المناهج الدرسية المتنوعة له أثر في } \\
& \text { بحاح تعليم وتطبيق الفقه لدى التلاميذ في الحياة اليومية، سواء في العبادة والمعاملة. } \\
& \text { الكلمات المفتاحية: الفقه، تطبيق المنهج با ـ ب، المدرسة الإبتدائية }
\end{aligned}
$$




\section{Introduction}

According to regulations No. 20 of 2003 on National Education System, national education serves to develop the ability and character development and civilization of the nation's dignity in the context of the intellectual life of the nation, and is aimed at developing students' potentials in order to become a pious person and fear of God the Almighty, noble, healthy, knowledgeable, skilled, creative, independent, and become democratic and responsible in all matters under their responsibility.

To achieve these objectives, school is one of the most important parts of the national education system in Indonesia. Moreover, the portion of the field of study of Islamic Religious Education (PAI) is quite large, it is intended to form the learners become a pious person and fear of God the Almighty and have noble character. Since the academic year of 2013/2014, the Government has implemented a new curriculum called "curriculum 2013" as a form of perfecting the development of School Based Curriculum (SBC/ KTSP) 2006 and Competency Based curriculum (KBK) 2004. This policies expect that this curriculum implementation will integrate the achievement target of every graduate from educational institutions into a system of graduate education level attainment (read: SKL/ Standard of Graduate Competence) and the target of achieving a core competency (KI) uniformly with no distinction and make no difference among subjects. Target achievement of the graduate competence is based on three main points, those are; the strengthening of the attitude (spiritual and social), comprehensive knowledge, skill and proficiency. If the target is "same", there is no difference of tasks among teachers of every subjects, all teachers have the same target, that is how learning can produce the graduates who have three abilities at once, ie, affective, cognitive and psychomotor.

The achievement of those three abilities will culminate in assimilating between the quality of the process and the final results to be integrated. For example, the attitude, an ability that is closely connected with the process of habituation, coaching, and giving examples simultaneously, there will be no correlation with aspects of knowledge. The formation of attitudes can only be done through a process of learning activities that able to form the learners into a 
figure with positive characteristics (akhläq al-karimah). Applying active learning methods, creative, innovative, and fun are the ways that teachers can do in order to realize the positive attitudes of learners.

Curriculum 2013 entry emphasizes the activities based learning. Therefore, the assessment will have more emphasis on the process; both in the aspect of attitudes, knowledge, and skills. Thus, it is required evaluation guidelines which provide a focus on the following matters:First, The assessment is directed to measure the achievement of basic competence in KI-1, KI 2 and KI KI-3-4.Second, The assessment uses reference criteria; which is based on what can be done by learners after the learning process, and not to determine what group a learner belongs to. Third, The planned system is a system of continuous assessment. Continous, in this sense is that if all the indicators were charged, then the results were analyzed to determine the $\mathrm{KD}$ which have been owned and which is haven't, and to analyze the difficulties of learners. Fourth, The results were analyzed to determine what needs to be followed-up. The matters than being followed-up to improve the next learning process, then, remedial programs is provided for students who haven't achieve the competence and provide enrichment program for students who have met the competences. Fifth, The assessment system should be tailored to the learning experience of students taken in the learning process. For example, if the approach to the task of learning using field observations, the evaluation should be given to both the process eg interview techniques, as well as products such results make a field.

\section{Challenges for Development}

Islamic education is necessary for Muslims, in order to understand the true teachings of Islam as a complete religion (kämil), the perfection of Islam who studied completely (käffah) is expected to improve the quality of the Muslims in all aspects of their life. Islamic teaching can be studied effectively and efficiently, it is necessary to develop the curriculum of Islamic education in accordance with the development and the demands of the today's era. Similarly, the subjects of Arabic indispensable as a tool to study and explore the primary sources of Islamic education which uses Arabic especially Qur'an and Hadith.

In addition to their formal legal provisions that require revision 
and refinement of the curriculum, the people of Indonesia and the people of the world changing very rapidly and in diverse dimensions associated with the life of the individual, society, nation and mankind. The phenomenon of globalization is opening its physical boundaries (territorial) state and nation sharpened and accelerated by advances in technology, especially information and communication technologies.

The advances in science strengthens the impact of globalization and technology. The changes that occurred in the past two decades beat the speed and dimension of the changes that occur in human life in previous centuries. The amendment was reaching human life from global, national, and regional as well as the life as human beings, citizens, and members of the public and private.Changes and improvements will be important as the continuity of all the possibilities that were related to the development of society, science, technology and art and culture at local, national, regional, and global in the future.

Jenlink (1995) states that the futures will bedramatically different from the present, and it is already calling us into preparation for major changes being brought to life by the forces of change that will require us to transcend current mindsets of the world we know It must be able to prepare a generation of people who could afford to live and to play an active role in the life of local, national, and global experience with such rapid changes. As disclosed by Oliva (1982), the curriculum should pay attention to the changes that occur in society, science, leadership, and politics. The changes mentioned above provide a strong basis for a change in the environment of school curriculum.

The fact that there is a legal mandate, and human life is changing rapidly which causes changes and improvements to the school curriculum are a necessity that can not be avoided. On that basis, the draft conceptual and contextual improvement of curricula becomes a necessity that must be prepared in advance. With the curriculum documents of Islamic and Arabic Studies, the Ministry of Religious Affairs has sought to transform the thinking that bridges everything that already exist today (what it is) with everything that is supposed to exist in the future (what should be next) in a curriculum design and actual functional in life.

In accordance with the policy and in particular assignment, then the Directorate General of Islamic Education outlines the aspects relating 
to curriculum development and strengthening the implementation of the curriculum by doing reconceptualization education unit curriculum ideas, curriculum design, curriculum implementation and curriculum evaluation.

Reconceptualization of the idea of the curriculum is a rearrangement of theoretical thinking competency-based curriculum. Theories about the competence and competence-based curriculum geared to the principal thought that the curriculum content is competence, and competence is defined as the ability to do something (ability to perform) for attitude, skills and knowledge. It is formulated in the core competencies (CC) and the Basic Competency (BC).

Provisions contained in the Strategic Plan of the Ministry of Religious show a clear direction that the new curriculum being developed need to care about those aspects of human potential that is associated with the domain attitude to the development of soft-skills, balanced with hard-skills, in line with the spirit of Islamic Education itself.

The design of the development of new curriculum should be based on the understanding that the curriculum is an educational pattern intact for the level of education. This design puts subjects as curriculum content organization that is open and influences each other. The design of a curriculum that will be used to develop a new curriculum should be able to associate between curriculum content both horizontally and vertically.Furthermore, the overall dimensions of curriculum development curriculum: the idea, design, implementation and evaluation of curriculum, planned in one unit. This is actually the core of curriculum development.

Curriculum development needs to be seriously undertaken because of the challenges faced, both internal and external challenges. In addition, in the face of the demands of the times, curriculum development is needed for improving the mindset and strengthening the governance system and the deepening and expansion of curriculum material. In addition, it is also important that there is a need to strengthen the learning process and learning load adjustment in order to ensure conformity between what is desirable with what is produced. 


\section{Curriculum Structure, Scope, and Learning Objectives for Fiqh Subject}

The structure of a group of subjects of Islamic Education and Arabic in the Madrasah curriculum includes: 1) Alquran Hadith, 2) Aqeedah Morals, 3) Jurisprudence, 4) Cultural History of Islam (SKI), and 5) Arabic. Each of these subjects are essentially interrelated and complementary.

Fiqh/Jurisprudence (sharīah) is a system or set of rules that govern the human relationship with Allah (hablu minallāh), neighborhood (hablumin al-nās) and other creatures (min al-nās-máal Ghayri). Characteristics of fiqh/jurisprudence emphasizes the correct understanding of the provisions of the law in Islam as well as the ability on how to conduct religious worship in a good and true practice in everyday life.

Substantially, subjects of Fiqh at Public Elementary School is one of the parts oflslamic Education subjectabout Jurisprudence of worship, especially concerning the recognition and understanding of the ways the implementation of the five pillars of Islam and it's behaving in everyday life, as well as Jurisprudence of muamalah, concerning the recognition and understanding a simple provision of food and drink(halal and haram), circumcision, sacrifices, as well as the procedures of buying, selling and borrowing.

Substantially, the Fiqh subjects also has contributed in providing motivation for learners to practice and to apply Islamic law in everyday life as the embodiment of harmony, and balancing the human relationship with Allāh Swt, with themselves, with othershuman beings, other creatures or the environment. Fiqh Subjects at Public Elementary School aims to equip students to be able to:

1. Knowing and understanding the ways of implementing Islamic law both concerning aspects of worship and muamalah as the way of life in personal and social life.

2. Implementing and adopting the Islamic law correctly and well, as the embodiment of obedience to the teachings of Islam both in human's relationship with Allāh Swt, with themselves, others humans, and other creatures as well as the relationship with the environment. 


\section{Analyzing the Essence of Fiqh Subjects Essential Meaning of Fiqh Subjects at Public Elementary School}

Fiqh subject is one of a group of subjects in the curriculum of Islamic Education. Literally, the meanings of Fiqh are smart, savvy, and understanding. While the Fiqh according Abd. Hamid Al-Ghazali (AsShidqy, 1996:26) is the science that explains the laws of Personality 'for mukallaf, such as; mandatory, forbidden, permissible, sunah, makruh, and authentic.

The term "shari"ah" or "tashri" is also often become the name of Fiqh. The word "tasyri" is the plural form of the word "syarra" means to create and to establish the sharia (Rosyada 2011:45).Shari'ah, according to Farouk Abu Zeid in (Syarifuddin, 2003:4) are all things established by God through His Prophet verbal. God is the maker of shari'ah concerning religious life and the world. The word Shari'ah appears in the Qur'an as follows:

1) Al-Maidah Verse 48: To each of you We prescribed a law and a method. Had Allah willed, He would have made you one nation [united in religion], but [He intended] to test you in what He has given you; so race to [all that is] good

2) Al-Syura' Verse 13: He has ordained for you of religion what $\mathrm{He}$ enjoined upon Noah and that which We have revealed to you

3) Al-Jasiyah Verse 18: Then We put you, [O Muhammad], on an ordained way concerning the matter [of religion]; so follow it and do not follow the inclinations of those who do not know.

Based on its legal subjects, tasyri is divided into two, namely: "tashri'"samāwī" and tasyri "wad’i". Tashri "samāwi" is a legal provision that has been established by God and the Apostles in the Qur'an and Sunah. Such a provision is permanent. While tasyri "wad'i" are legal terms laid mujtahid. These regulations are not immortal nature, because the decision was influenced by the agreement to take into account the experience, environmental conditions, in-depth discussions, and conditions at the time. The results of this study, called tasyri " wad' $i$ " or fiqh.

Then Fiqh (shari'a) is a system or set of rules that govern the human relationship with Allah (hablu min alläh), neighbor (minannās-min an-nās) and other creatures (min an-näs-máal ghayri). Human's relationship with God (hablum-minallah) is a Muslim devotion to the Creator, to carry out His commands and avoid His prohibitions. While 
the definition of hablum-Minan-nass is to maintain good relations with fellow human beings, through the love and spread the goodness among others. Islam also teaches about the relationship with other creatures through the concept hablum-ma'al Ghairi.

The concept of the relationship between human and God are two forms, a form of devotion to God directly, and secondly, a form of devotion to God that is translated into good deeds to fellow creatures of Allah (Syarifuddin, 2003:12). Qur'an teach the following verses:

1) Al-Bayinah verse $5:$ And they were not commanded except to worship Allah

2) Al-Zariyat verse 56: And I did not create the jinn and mankind except to worship Me.

3) Ali Imran verse 112, They have been put under humiliation [by Allah] wherever they are overtaken, except for a covenant from Allah and a rope from the Muslims. And they have drawn upon themselves anger from Allah and have been put under destitution. That is because they disbelieved in the verses of Allah and killed the prophets without right. That is because they disobeyed and [habitually] transgressed.

Fiqh subjects taught in Islamic elementary schools would not only load in the implementation of learning theory, a change in behavior and implement good practice in worship and muamalah also became the main feature of these subjects. Providing the basis for the whole development of human potential learners become qualified to serve as the philosophical basis of Fiqh learning in development that are aligned with national education goals.

The next steps are the basic dynamic development Fiqh subjects according to the curriculum in 2013, the first, learning undertaken by teachers in the form of a process developed in the form of learning activities at the school, classroom, and community. Second, the direct experience of learners, in accordance with the background, and the ability of early learners. The results of these activities are divided into two types, direct learning experience individually the learning outcomes for learners and overall learning outcomes to be part of the development of the curriculum itself. This is precisely what became the theoretical foundation in the development of learning Fiqh for Islamic elementary schools.

Learning Fiqh in Elementary School can not be separated from 
the form of the implementation of the national education goals in the realm of spiritual attitudes that form the learners that is being pious and doing the righteous. That purpose in the 2013 curriculum is developed in accordance progressivism education philosophy, which makes the core competencies of stairs to climb to the competence of graduates which must be taken by every learner.

As a form to ease the learners to steer the process towards competency of graduates are multidimensional, held division of the core competencies in the realm of attitudes itself. First, the spiritual attitude in accordance with the objectives of national education in an effort to form learners is that is being pious and doing the righteous. Second, a social attitude that seeks to form students that are noble, independent, democratic, and accountable. Its core competencies are the charges that will be paid by the subjects in each of the learning process.

In accordance with the Law on National Education System No. 20 of 2003 which states that, competency must meet the attitudes, knowledge, and skills, then the sequence of core competence in the subjects of Fiqh is as follows: KI1, for Core Competence of Spiritual Attitude; Ki2, for Core Competence of Social Attitudes; KI3, for Core Competence of Knowledge Attitude (understanding of concepts); and KI4, for Core Competence of skills.

As a form of support to core competencies, then developed a derivative form of the basic competencies of subjects. The formula was developed by noticing the characteristics of learners, prior knowledge, and characterizes subjects as supporting the achievement. Basic competencies are grouped into four based on the core competence supports, namely: basic competency spiritual attitudes (support KI-1) or groups 1 and 2, a group of basic competence social attitudes (support KI-2) or group 2 and 3, a group of basic competences knowledge (supports KI-3) or groups 3 and 4, and a group of basic competency skills (supports KI-4) or group 4. The process continues to bridge that knowledge on the skills, and develop into an attitude, so rigging among three closely linked in the process of learning.

Their learning process integral is expected to direct learners to meet the competency standards that have been designed, as described in Article 35 of Law No. 20 of 2003 which states that the competency 
standards is the ability qualification of graduates that includes attitudes, knowledge, and skills that learners must be fulfilled or the achievement of an educational unit on the level of Elementary school, Middle School, and High School.

Elementary School expects its graduates to be able to have the attitude, knowledge and skills of the following:

Table 1

Dimension and Qualification of Competences in Curriculum 2013

\begin{tabular}{|ll|}
\hline Dimension & Qualifation of Competences \\
\hline Attitudes & $\begin{array}{l}\text { Behavior that reflects the attitude of the faithful, noble, } \\
\text { confident, and responsible to interact effectively with the } \\
\text { social and natural environment in our homes, schools, and } \\
\text { playgrounds }\end{array}$ \\
\hline Knowledges & $\begin{array}{l}\text { Has a factual and conceptual knowledge based on curiosity } \\
\text { about science, technology, art, and culture in the knowledge } \\
\text { of humanity, national, state, and civilization-related } \\
\text { phenomena of events in the home environment, schools, and } \\
\text { playgrounds. }\end{array}$ \\
\hline Skills & $\begin{array}{l}\text { Having the ability to think and act of productive and creative } \\
\text { in the realm of the abstract and the concrete in accordance with } \\
\text { what assigned to them. }\end{array}$ \\
\hline
\end{tabular}

Source: taken and compiled from Curriculum 2013 competence standard

Dimensions attitude that has been described on the ability qualification requires acquisition process for each learner. Characteristics, suitability, adequacy, breadth, and depth of the material is determined according to the characteristics of competence along with the competence acquisition process. All three of these competencies have a different derivation process. Attitudes formed through activities: receiving, running, cherish, appreciate and practice. Knowledge acquired through activities: to know, understand, apply, analyze, evaluate, and create. Skills acquired through activities: observe, ask, try, reasoning, present, and create.

The derivatives is according to the characteristics of competence lowered according to the subject they teach. Fiqh subjects emphasize a correct understanding of the provisions of law in Islam as well as the ability to practice their religion and muamalah in a righteous way and 
correct in everyday life. Learning was directed learners to practice and apply Islamic law in everyday life as the embodiment of harmony, and balance the human relationship with Allāh Swt, with themselves, other humans, other animals or the environment.

Fiqh subjects Elementary School aims to equip students to be able to: Know and understand the ways the implementation of Islamic law both concerning aspects of worship and muamalah to be a way of life in personal and their social life. Implement and adopt the Islamic law correctly and well, as the embodiment of obedience to the teachings of Islam both in human's relationship with Allāh Swt, with with themselves, fellow humans, and other creatures as well as the relationship with the environment.

The scope of Fiqh subject emphasizes the muamalah and ibadah. Fiqh of worship have regarding coverage; recognition and understanding of the procedures of the pillars of Islam that is true, like ordinances for taharoh, prayer, fasting, zakat and hajj. Whereas the scope of Fiqh muamalah cover provision of food and beverages that is halal and haram, circumcision, sacrifices, as well as the procedures for buying, selling and borrowing. Fiqh is also directed to lead learners can understand the main points of Islamic law and the procedures for its implementation to be applied in life, so that a Muslim is always about following Islamic law in käffāh (perfect).

The process of organizing learning Fiqh subject, must be arranged in an interactive, inspiring, fun, challenging, motivating the students to actively participate and provide enough space for innovation, creativity, and independence in accordance with their talents, interests, and the development of physical and psychic learners. Every initiate the convening of learning, three important components must be the essence, namely; planning, implementation, learning, and assessment in the learning process, in order to obtain the efficiency and effectiveness of achievement of competencies of graduates.

Acquiring competence in the implementation of effective and efficient learning in learning Fiqh should also refer to the following principle: from learners are given out into learners to find out; of educators to be the only source of learning-based learning into a variety of learning resources; of a textual approach to the process as strengthening the use of a scientific approach; from content-based learning towards 
competency-based learning; of partial learning towards an integrated learning (integral); of learning that emphasizes the single answer to the multi-dimensional learning that the answer; of verbal learning towards learning applicable; increase and balance between physical skills (hard skills) with the mental skills (soft skills); learning that promotes cultivation and empowerment of students as lifelong learners; learning to apply the values and principles by giving exemplary (ing ngarso sung tulado), willingness to build (ing madyo Mangun Karso), and developing the creativity of learners in the learning process (tut wuri Handayani); learning that takes place at home (informal), at school (formal), and in the community (non-formal); learning to apply the principle that anyone who is an educator, who are learners, and anywhere is a class place of learning; utilization of information and communication technologies to improve the efficiency and effectiveness of learning; and the recognition of individual differences and cultural background of learners.

\section{Fiqh Learning in Elementary School}

The learning process is consistent with the objectives of the national education involve teachers in their implementation. Teachers have a role to create effective classroom, so that learning becomes meaningful, and the results referred as in the mandate of the law. The learning process should be in accordance with the curriculum. The curriculum becomes a reference in determining the objectives, content, materials, and strategies on any learning process that takes place (Rusman in Saud and Ariesta 2016: 9).

A teacher who is planning the learning process should pay attention to several elements, namely; learning objectives, content or learning materials, learning model, instructional media, and evaluation. Overall these elements should be integrated into a single entity in the implementation of learning (Dahar, in Saud and Ariesta 2016: 9).

The ability to create lesson plans undertaken by teachers is one of the pedagogic abilities that must be owned by each educator. The quality of the preparation of lesson plans affect the effectiveness of the implementation of learning, which is expected to achieve optimum results in the process (Susilana, 2014:91). The existence of two-way 
communication between teachers and learners is one reflection of the successful implementation of learning.

Speaking of learning would always put teachers and learners in a leading role in it. Both are holding a strategic position to bring the ark of learning in order to get to its planned destination. Teachers as educators must forge themselves, to be able to be disseminator, informatory, transmitters, transformers, organizer, facilitator, motivator and evaluator for the sake of creating a dynamic and innovative learning (Susilana, 2014: 9.3). Readiness of students both spiritually and temporally for implementing learning is also a very important factor, in order to achieve the desired objectives. Both have a role in the effort as well as cooperation in the field of learning in the classroom.

Fiqh learning in Islamic elementary schools should be implemented in an interesting way, so that students are able to know, understand, implement, and make Islamic law can be implemented as an established practice in daily life.

The concept of worship and muamalah in learning Fiqh for Elementary School took a meaning; worship is all the effort both physically and spiritually to carry out the commands of God in order to happiness outwardly and inwardly, for the sake of harmony of life, both for the lives of self, family, society, and the universe (Syarifuddin, 2003: 17). While muamalah derived from the word amala said to have understanding, mutual acts or act reciprocally, that is the relationship between a person with another person in the association in the world (Syarifuddin, 2003:17).

Aspects of worship and muamalah on Fiqh taught in Elementary School curriculum includes:

Table 2

Materials for Fiqh Subject for elementary school

\begin{tabular}{|cl|}
\hline Class & \multicolumn{1}{c|}{ Materials } \\
\hline I & 1. Pillars of Islam, Syahadatain, and Purification of Hadas and \\
& bouquets \\
& 2. Memorizing Wudu and Prayer After Wudu \\
\hline II & $\begin{array}{l}\text { 1. Adzan, Iqomah, and Praying } \\
\text { 2. Prayer in congregation, Dhikr, and activities after Prayer }\end{array}$ \\
\hline
\end{tabular}




\begin{tabular}{|c|c|}
\hline III & $\begin{array}{l}\text { 1. Prayer of Sunat Rawatib, Prayer of Jama and Qasar, Tayamum, } \\
\text { and praying for sick people } \\
\text { 2. Fasting Ramadan, Prayer of Sunat Tarawih, Witir, and Practicing } \\
\text { primacy deeds in Ramadan }\end{array}$ \\
\hline IV & $\begin{array}{l}\text { 1. Zakat, Infak, and Sadakah } \\
\text { 2. Friday prayer and Idain Prayer }\end{array}$ \\
\hline $\mathrm{V}$ & $\begin{array}{l}\text { 1. Circumcision and Purification of Menstruation } \\
\text { 2. Sacrifice, Hajj and Umrah }\end{array}$ \\
\hline VI & $\begin{array}{l}\text { 1. Food, Beverages, and Halal and Haram } \\
\text { 2. Buying, Selling and Borrowing Activities }\end{array}$ \\
\hline
\end{tabular}

Source: compiled from the Ministry of Religious Affairs Books 2015

In the implementation of learning, teachers use teaching methods that is appropriate to the characteristics of learners. The use of interesting methods and in accordance with the essence of the material being taught will be part of the success of the learning program

Playing, storytelling, exemplary, and habituation is an effective method applied in teaching Fiqh for Elementary School. Playing method can be applied to a game of function or motion, this method can also be implemented with the illusion and receive or receptive some games (Prastowo, 2015:141). The game of functions and motion applied to the material of pilgrimage. While the game of illusion could be implemented for material of Hajj and fasting. While the game that is intended to be a receptive, it could use storytelling. Games and entertainment are activities to foster the spirit for learners, with participation expected to develop manners, good habits, and the development of their knowledge (Comenius in Prastowo, 2015:141).

The use of storytelling in learning Fiqh in Elementary School is very good, since children have anthromorph properties, egocentric, imitative, wondering (Sa'diah in Pratowo, 2015: 141). The strength is expected as the exact path in an effort to foster a good memory and educate, stimulate the development of imagination, and growing activity pattern that is a reflection of the good things that absorbed in the stories. Storytelling is very useful for the: evokes feelings of fear, pleasure, and love of God; directing the entire feeling of learners, so they will looking forward to a conclusion to the story, and the 
involvement of learners in each story will arouse them emotionally.

Modeling becomes the third method recommended in learning Fiqh Elementary School. Modeling will be effective in teaching, known that every student will mimic the nature (imitative). The role of the teacher is vital, given the imitation of the important aspects that lead to the development of learners in learning Fiqh in Elementary School. Teacher is the primary mirror in worship and muamalah activity for students.

The fourth method is habituation. Habituation is a repetition of activities and it would be optimal way if there is a pattern of discipline in its implementation. The example of this application is performing $d u b a$ or zuhür congregational prayer in school, which will foster a pattern of habituation for learners. A regular pattern applied in the school is very likely going to be learners habit when they are out of school. When the congregation behaviors already entrenched in them, then they will feel uncomfortable to leave the habit, although it was not in the monitoring of teachers in the school.

\section{Authentic Assessment in Fiqh Teaching at Elementary School}

Authentic Assessment is a meaningful measurement significantly over the study of students to the realm of attitudes, skills and knowledge. Assessment term is synonymous with measurement, testing, or evaluation. The term Authentic is synonymous with original, real, valid or reliable. When implementing authentic assessment to determine the results and achievements of learners, teachers apply the criteria relating to the construction of knowledge, the activity observed and tried, and outside of school achievement scores.

The following table interpret the authentic assessment techniques; to the realm of attitudes, knowledge, and skills.

Table 3

Technique of Authentic Assessment

\begin{tabular}{|ll|}
\hline Assessment Technique on Authentic Assessment \\
\hline Attitude & 1. Observation \\
& 2. Reflecting journal \\
& 3. Peer-Assessment \\
4. & Teachers' log \\
\hline
\end{tabular}




\begin{tabular}{|lll|}
\hline Knowledge & 1. & Written Test \\
& 2. & Verbal test \\
& 3. & Assignment \\
\hline Skills & 1. & performance \\
& 2. & Project \\
& 3. & Portfolio \\
\hline
\end{tabular}

Source: The concept of Authentic Assessment for Process and Learning Outcomes, Agency for Human Resources Development, Education and Culture and Quality Assurance of Education, Ministry of Education and Culture

Authentic assessment tries to combine the activities of teachers teaching, students learning activities, motivation, and engagement of learners, as well as learning skills. The concept of authentic assessment in Fiqh lesson in Islamic elementary schools, should also engage the learners. The assumption is that the learner can perform the activities better when they know how it will be assessed. Teachers involve the learners in carrying out this task. This is very meaningful for their personal development.

Authentic assessment consists of a variety of assessment techniques. First, the direct measurement of skills learners associated with longterm educational outcomes such as successful in the workplace. Second, the assessment of the tasks that require the involvement of a broad and complex performance. Third, the analysis of the process used to produce a response of learners on the acquisition of attitudes, skills and knowledge.If the teacher has planned an authentic assessment in the classroom, then these kinds of assessments should be carried out as follows: 1. Performance Assessment, 2. Assessment Project, 3. Portfolio Assessment, and 4. Written Assessment.

Authentic assessment should as far as possible involve the participation of learners, especially in the process and the aspects to be assessed. Teachers can do this by having participants mention the elements of projects / tasks that they will use to determine the criteria for its completion. To record a performance-based assessment results, the following are the steps for teachers to develop: (1) checklist. (2) anecdotal/narative records. (3) rating scale. (4) memory approach.

Project Assessment is an assessment of the tasks to be completed by learners by period/specified time. Completion of tasks referred to in the form of investigations conducted by learners, ranging from planning, 
data collection, organizing, processing, analysis, and presentation of data. Three important things to be noticed by the teacher in the assessment of the project are:

First, skills of learners in choosing the topic, look for and collect data, process and analyze, give meaning to the information obtained, and write reports.

Second, compliance or the relevance of learning materials with the development of attitudes, skills and knowledge needed by learners.

Third, the authenticity of a learning project that done or produced by learners.

The third type of assessment in authentic assessment is a portfolio assessment. Portfolio assessment is an assessment of a collection of artifacts that show the progress and appreciated as the work of the real world. Portfolio assessment can depart from the work of the students individually or in groups produced, requires reflection of learners, and evaluated based on multiple dimensions.

If the portfolio assessment will be applied, then the steps that must be prepared by the teacher are as follows: (1) Teacher explains briefly the essence of portfolio assessment. (2) The teacher and students determine what type of portfolio to be created. (3) Learners, either alone or in groups, independently or under the guidance of teachers prepare learning portfolios. (4) Teachers collect and store portfolio of learners in the appropriate place, with a record date of its collection. (5) Teachers assess learners' portfolios with certain criteria. (6) If possible, teachers along with the students sit together to discuss the portfolio documents to be produced. (7) The teacher gives feedback to learners on the assessment portfolio.

The fourth type of assessment is a written assessment. Written test or essay form description requires that learners to be to able to remember, understand, organize, implement, analyze, synthesize, evaluate, and so on the material that have been already learned. The written test descriptions should be compiled in comprehensive form to describe the realm of attitudes, knowledge, and skills of learners. 
Table 4

Example of Authentic Assessment Sheet

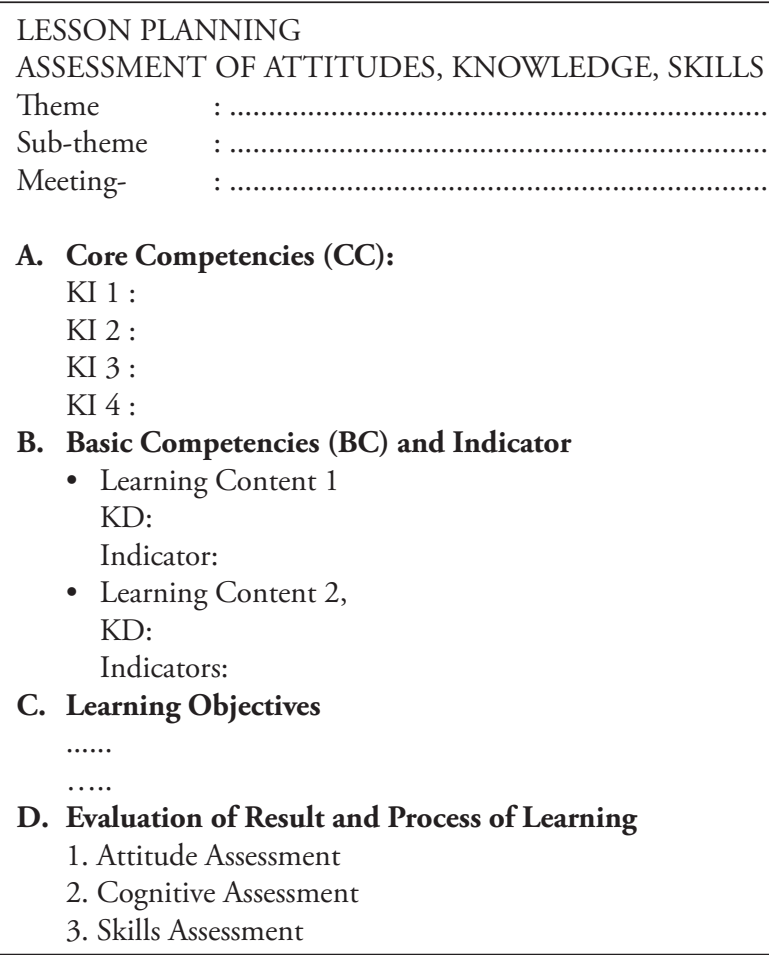

A. Core Competencies (CC):

KI 1 :

KI 2 :

KI 3 :

KI 4 :

B. Basic Competencies (BC) and Indicator

- Learning Content 1

$\mathrm{KD}$ :

Indicator:

- Learning Content 2,

$\mathrm{KD}$ :

Indicators:

C. Learning Objectives

D. Evaluation of Result and Process of Learning

1. Attitude Assessment

2. Cognitive Assessment

3. Skills Assessment

\section{Conclusions}

Fiqh subject in public Islamic elementary schools is an attempt to achieve national education goals in the realm of spiritual attitudes that form the learners who believe and do the righteous. The purpose of the study is not only directs students in scientific understanding only, but also refers to the development of attitudes and behaviors as habits of learning outcomes. Implementation of learning pursued in accordance with the elements of the curriculum that has been designed. The learning process must also meet the criteria of implementation: Planning, learning process, and evaluation of the basis for determining the quality of the learning Fiqh in the Elementary School. The use of varied methods is also a way to achieve a success in learning Fiqh for Islamic elementary schools according to the curriculum in 2013.[] 


\section{References}

Amberi, Mazrur, "Pembelajaran Fikih di Madrasah (Mencari Model di Tengah Perbedaan)”, Jurnal Tarbiyatuna Pendidikan Agama Islam Vol. 1 No. 1 , Jurusan Tarbiyah STAIN Palangkaraya, 2011.

Konsep Penilaian Autentik Pada Proses dan Hasil Belajar, Badan Pengembangan Sumber Daya Manusia Pendidikan Dan Kebudayaan Dan Penjaminan Mutu Pendidikan, Kementerian Pendidikan dan Kebudayaan.

Mukaromah, Ulfatun, "Pengembangan Sumber Belajar Fikih Di MA Minat Kesugihan Cilacap" Skripsi Pendidikan Agama Islam Fakultas Tarbiyah dan Ilmu Keguruan Institut Agama Islam Negeri Purwokerto, 2016.

Nasirrudin, "Pendidikan Fikih Berbasis Kompetensi" Jurnal Pendidikan Islami Vol. 14 No. 1, 2005.

Prastowo, Andi, "Keselarasan Materi Fikih MI Kurikulum 2006 Terhadap Karakteristik Perkembangan Peserta Didik" Jurnal Pendidikan Agama Islam Vol. 7 No. 2, Yogyakarta: Program Studi PGMI, Fakultas Ilmu Tarbiyah dan Keguruan UIN Sunan Kalijaga Yogyakarta, 2015.

Sa'diyah, Siti, "Metode Pendidikan Bagi Pengembangan Rasa Agama Pada Anak Usia Awal" Jurnal Pendidikan Agama Islam Vol. II No. 2, Yogyakarta: Jurusan PAI, Fak. Tarbiyah UIN Sunan Kalijaga, 2005.

Saud, Abdul Mumin, "Peningkatan Aktivitas Belajar Siswa dengan Menggunakan Model Pembelajaran Picture and Picture pada Pembelajaran IPS SD Kelas V", Pengembangan Kemampuan Berpikir Kritis, Kreativitas, Komunikasi, Dan Kolaborasi Dalam Pembelajaran Abad 21: Inovasi Pembelajaran Abad 21, Bandung: Universitas Pendidikan Indonesia, 2016.

Sayrifuddin, Amir, "Garis-Garis Besar Fiqh”, Jakarta: Prenada Media, 2013.

Susilana, Rudi, "Rencana Pembelajaran" Pengembangan Kurikulum dan Pembelajaran di SD, Tangerang Selatan: Universitas Terbuka, 2014.

Zain, Lukman, "Pembelajaran Fikih" Pengembangan Peningkatan Kualifikasi Guru Madrasah dan Guru Pendidikan Agama Islam Pada Sekolah, Jakarta: direktorat Jendral Pendidikan Islam Departemen Agama RI, 2009.

Fauzan \& Anis Fuadah Zuhri, Faculty of Tarbiyah and Teachers Training UIN Syarif Hidayatullah Jakarta, Jl. Ir. H. Juanda 95 Ciputat, Jakarta Selatan, E-mail: fauzan@uinjkt. ac.id, anisfuadah.zuhri@uinjkt.ac.id 


\section{Ahliam}

AHKAM Jurnal Ilmu Syariah (ISSN: 1412-4734/E-ISSN: 2407-8646) is a periodical scientific journal published by Faculty of Sharia and Law of Syarif Hidayatullah State Islamic University Jakarta in collaboration with Indonesian Scientist and Sharia Scholar Association (HISSI). This journal specifically examines the science of sharia and obtains to present various results of current and eminence scientific research. The administrators receive articles as contributions Sharia and Islamic law disciplines from scientists, scholars, professionals, and researchers to be published and disseminated. The article will be situated in a selection mechanism, a review of proved reders, and a strict editing process. All articles published in this Journal are based on the views of the authors, but they do not represent the authors' journals or affiliated institutions.

AHKAM has been accredited based on the determination of Director General of Research Reinforcement and Development, Research, and Technology Ministry of Higher Education of Republic of Indonesia, No. 36/a/E/KPT/2016 (valid until 2021). 